\title{
The 2007 Dutch Reformed Church Synod Resolution: Impact on gay ministers
}

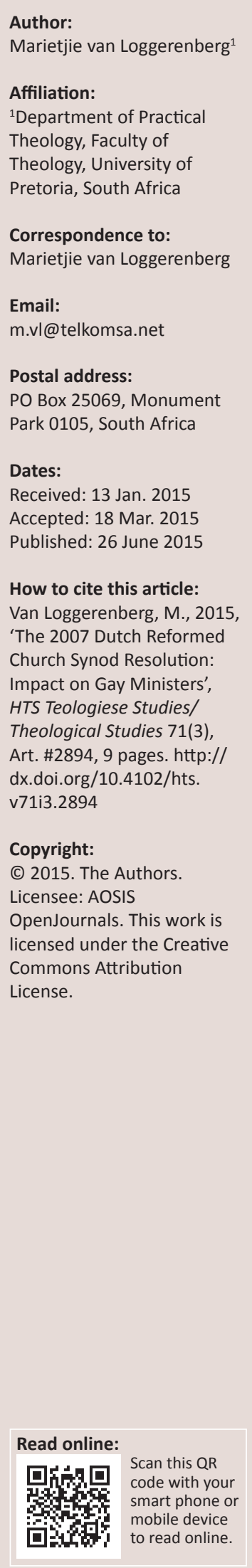

At the 2007 General Synod of the Dutch Reformed Church (DRC), a compromise resolution was accepted regarding homosexual members. The resolution, inter alia, requires of gay ministers to remain celibate as a prerequisite to be legitimated. This research is a qualitative inquiry to evaluate the impact this resolution has on the lives of gay ministers and gay candidate ministers. Apart from doing a literature study Narrative and Post-foundational perspectives were obtained by interviewing six gay ministers and/or candidate ministers as co-researchers, and also by engaging in dialogue with interdisciplinary experts from Sociology, Psychology and Law. From the stories told by the gay ministers and/or gay candidate ministers, certain themes emerged, revealing the immense impact caused by the resolution.

\section{Background}

At the 2007 General Synod of the Dutch Reformed Church (DRC) a compromise resolution regarding homosexual members was accepted. One of the principles of this Resolution was a requirement that gay ministers should remain celibate. This article is based on a qualitative inquiry to evaluate the impact this Resolution has on the lives of gay ministers and gay candidate ministers (co-researchers in this context). Narrative and post-foundational perspectives were obtained by interviewing six gay ministers and/or gay candidate ministers as co-researchers, and also by engaging experts from other disciplines (Sociology, Psychology, Law) in dialogue after they had read the stories of the co-researchers.

The gay debate in the DRC was formally introduced during the General Synod of 1986, when homosexuality was seen as a deviate form of sexuality, and gay practices and gay relationships disapproved of because they were opposing the will of God (Algemene Sinode [NGK] 1986:672). During synods to follow (Algemene Sinode [NGK] 2002:628; Algemene Sinode [NGK] 2004:433; NGK Suid-Transvaal 2001), much progress has been made in terms of accommodating gay people. During 2005, the moderamen of the General Synod appointed a task team to investigate the issue of homosexuality further and to serve the General Synod of 2007 with a report. Eventually a compromise resolution entailing the following principles with regard to homosexuality was approved of (Algemene Sinode [NGK] 2007:8 - my translation from Afrikaans):

1. The Bible is our point of departure and in reflecting on homosexuality we are sincerely looking at ways to interpret biblical values meaningfully within the context.

2. We accept the love of Christ as the only valid basis for relationships within the community of believers. All people are created in the image of God; the salvation in Christ is for all people and the Spirit was poured out on all believers. Thus we accept the human dignity of all people.

3. All people, regardless of their sexual orientation, are included in God's love. They are accepted as members of the church of Christ based on their baptism and their faith. With membership we understand access to the sacraments, access to the incumbency and submission to the church discipline.

4. The General Synod reaffirms the decision of 2004 that, according to our understanding of the Bible, only the union between one man and one woman can be seen as a marriage.

5. The General Synod also affirms the decision of 2004 that both heterosexual and homosexual promiscuity should be condemned in the strongest terms.

6. The General Synod decides that, in light of how we currently see things, homosexual unions and marriages cannot be accepted as an alternative for the marriage.

7. The granting of ministership is a function of the General Synod. The Synod decides that homosexual legitimates who lead a life of celibacy be granted ministership.

8. The General Synod acknowledges the discretion of local church councils to handle the differences on homosexuality in congregations in a spirit of Christian love. 
With one addition ${ }^{1}$, the same principles were reaffirmed during the General Synod of 2013.

The principles contained in the resolution were interpreted by many commentators as huge progress (Oosthuizen 2007:3; Pienaar 2007:3), while gay people viewed it as rejection, reiterating the shame (Cilliers 2011:413; Downs 2006:3,4). The one persistent challenge in resolving the gay issue, especially for gay ministers in the DRC, remains their intimate relationships/ marriages.

\section{Research problem: The aftermath of the resolution}

Five years after the resolution was accepted, a situation arose calling for the resolution to be publicly applied. The result was that a theology student (Lulani Vermeulen²) was refused legitimation based on her same-sex relationship (Algemene Sinode [NGK] 2007:8; Jonker 2012:13). The case received much publicity in the printed and social media. Both church leaders and the laity had to face a matter that had been under the radar for five years.

Up till 2012, no formal research had been done to evaluate the impact of the resolution on gay ministers and gay candidate ministers.

The research problem addressed in this article is that no one is able to declare authoritatively what the resolution of 2007 meant for gay ministers and gay candidate ministers. It goes without saying that the consequences of any decision are important for maintaining and sustaining the decision, even more so when people's lives are at stake.

\section{Research objective}

The objective of this research was to acquire an understanding of the impact on gay ministers and gay candidate ministers after being subjected to the implementation of the Resolution.

\section{Conceptual framework}

I positioned myself as a researcher within the postfoundationalist epistemology. As opposed to both modernism (foundationalism where universal truths are selfevident), as well as post-modernism (non-foundationalism where truth becomes relative to the context), Müller (2011:2) and Van Huyssteen (1993:376) argue for a postfoundationalist approach of doing theology. The postfoundational approach moves beyond the boundaries of the foundationalist and non-foundationalist perspectives by focusing on interdisciplinary research through its language of transversal reasoning (Müller 2011:2, 4). According to Van Huyssteen (2007:5), post-foundationalism underscores

\footnotetext{
1.During the General Synod of 2013 it was decided that both homosexual and heterosexual students preparing themselves for the ministry in the DRC should comply with the same Christian-ethical standards for purposes of legitimation (Algemene Sinode [NGK] 2013a).

2.All names used in this thesis are either real names or pseudonyms, used with the permission of the persons referred to.
}

the notion that human experience is shaped by a complex network of beliefs. He suggests that, cognitively, we want to understand and explain our world by interpreting our experiences, but also by critically evaluating them. Müller refers to Van Huyssteen, who views transversal rationality not as indiscriminately opening up or closing down to other viewpoints. It is rather about discovering an epistemic space where interdisciplinary critical evaluation, including a critical self-evaluation and optimal understanding, can take place. Van Huyssteen (2000:239) makes us aware that:

$[W]$ hen we discover the shared richness of the resources of rationality without attempting to subsume all discourses and all communities under one universal reason, we have discovered the richness of a postfoundationalist notion of rationality. (Van Huyssteen 2000:239)

Müller (2011:5) encourages the opening up of boundaries between theology and other disciplines, because it can lead to an increased sensitivity for the human condition, especially in marginalised communities like the gay communities. A post-foundational approach forces us to listen to the stories of people in specific real life situations. This way of thinking is thus always local, concrete and contextual, but is also aware of how our epistemologies are shaped by tradition. It seeks a balance between our traditions of interpretations of experience and the broader network of beliefs in which our 'rationally compelling experiences are already embedded' (Müller 2011:3).

In accordance to the post-foundational paradigm, I followed a narrative approach in conducting my research. The narrative approach is based on the social-constructionist paradigm (Müller \& Schoeman 2004), which formed a conceptual basis for my qualitative research (Clandinin \& Connely 1994:416; Müller 2005:79). According to the socialconstructionist paradigm, reality is socially constructed through language and organised and maintained through narrative, without recognising essential truths. This paradigm supports the notion that we cannot know reality objectively; we can only interpret and describe experiences within a specific context (Freedman \& Combs 1996:22). My narrative enquiry was a qualitative inquiry into the lives of gay ministers and gay candidate ministers. According to Schwandt (1994:118), qualitative inquiry is profoundly concerned with understanding what other human beings are doing or saying. I further opted for participatory action research (McTaggert 1997:29), because it offered me the possibility to develop a balanced relationship between the co-researchers and myself, thereby avoiding exploitation. Participation reduced the distance between the co-researchers and me (Heshusius 1994:15-18). This approach stands in stark contrast to the approach followed by the DRC when they compiled the compromise resolution on gay people. The process excluded gay people, thereby embarking in a decision-making process that would hurt and not heal (see Kotzé 2002:4). At the 2013 General Synod meeting the moderator, Dr Niemandt, acknowledged this by apologising for having treated gay people as objects 
through their exclusion from continuous debates about them instead of including them in the DRC's deliberations (Jackson 2013:3).

\section{Research methodology}

According to Müller (2005:84), specific discourses or traditions in certain communities and faith-based organisations inform perceptions and behaviour. Similarly, specific discourses or traditions informed the resolution. The co-researchers and I had to identify these discourses in order to gain some understanding on how the formulation of the resolution was influenced by these discourses. We identified the discourses by listening to the co-researchers' stories, but also by listening to the voices of literature and informative theological traditions. The described experiences from the stories and the literature were thickened through interdisciplinary dialogues (Morgan 2000:74; Van Huyssteen 1993:376).

\section{Literature review}

I consulted literature on the development of the gay story of the DRC and on how the resolution came into being (Van Loggerenberg 2008). After the discourses informing the resolution were identified I explored the social construction of these discourses in order to gain some understanding of how they could influence the formulation of the resolution. In order to gain a better understanding on gay relationships I listened to the voices of pre-modern, modern and postmodern times in this regard.

\section{Narrative interviews}

I invited six gay ministers and/or gay candidate ministers who acted as co-researchers. They represented the following groups:

- Three gay candidate ministers who studied theology at the University of Pretoria (UP), the University of Stellenbosch (US) and North West University (NWU), who have been denied legitimation.

- A gay, celibate minister in the DRC who had been legitimated.

- A retired, gay, celibate minister from the DRC.

- A gay, former DRC minister who was forced to resign.

Where co-researchers preferred to remain anonymous, their identities were protected.

\section{Interdisciplinary dialogues}

In consultation with the co-researchers I invited Ms. Wezet Botes from Social Work, Professor Wilhelm Jordaan from Psychology and Professor Marinus Wiechers from Law as interdisciplinary participants. The interdisciplinary participants gave me permission to use their names in the research. I requested each interdisciplinary participant to reflect on the following questions which were adapted from an article by Müller (2009:207) on interdisciplinary work in the context of HIV and AIDS from the perspective of their own disciplines:
- When reading the stories of gay ministers and gay candidate ministers, what are your concerns?

- What do you think is your unique perspective from your own discipline on these stories?

- Why do you think your perspective would be understood and appreciated by people from other disciplines?

- What would your major concern be if the perspective of your discipline might not be taken seriously?

\section{Findings \\ Literature review}

The discrimination in the resolution against gay people, especially gay ministers, is understood as being informed by patriarchal and hetero-normative discourses with their truth claims that dominant masculinity and heterosexuality are universal values (McLean, Carey \& White 1996:13). Dreyer (2008a:739) considers the dominance of hetero-normativity to be based on an essentialist view on sexuality without acknowledging that sexuality is socially constructed and that perceptions about it can change over time. Dreyer (2008a:739, 740) also suggests that the church has not yet been transformed by the gospel of inclusive love, because the church bases its ideas on gay marriages on 'positivist ethical reading of the New Testament'. As opposed to a positivistic view on sexuality, Dreyer proposes a postmodern view on sexuality, which can be seen as the result of an endless variety of ever changing factors. Schillebeeckx (Hilkert 2005:380) argues that all authentic understanding should be done by creating a historical frame of reference which acknowledges the differences from the past and their claim on us, and that this claim may differ from our contemporary cultural frame of reference. He thus claims the necessity of reinterpretation of all understanding. In order for a text or a tradition to survive, Schillebeeckx considers as a requirement an on-going, new appropriation of its meaning in different historical contexts.

In terms of deconstructing the resolution, the first point of the resolution is seen as insincere, as gay people are only conditionally accepted in the DRC. Point 7 is seen as overruling point 1 in the resolution. If they do not remain single they are shunned from church life and experience their human dignity as harmed. This could be an indication that the DRC still views gay relationships as an abomination before God.

The second point in the Resolution contradicts the church ordinance, which states that all positions in the church are of equal value (Algemene Sinode [NGK] 2013b:2). By treating gay ministers differently, it suggests that God's love for gay people and the DRC's love for gay people were not regarded the same. The third point disregards gay marriages as marriages and is perceived as discriminatory. In this matter the DRC is actually falling behind the rest of the world and may just discover that as a church it has lost its relevance in many of their members' lives. It also shows a complete disregard for scientific evidence with suggestions 
of how people become hetero or homosexual (Van Zuydam 2014), thereby banning gay ministers to a life of loneliness and possible depression and various kinds of anti-social behaviour (Bontempo \& D'Augelli 2002:364-374; Cacioppo et al. 2002:407; Cacioppo et al. 2006:140).

The fifth point which condemns promiscuity for both homoand heterosexual people may sound fair, but remains vague in terms of defining promiscuity. Furthermore, this principle contradicts points 4, 6 and 7 which ban gay unions and gay marriages as un-Christlike, while also expecting from gay ministers to remain celibate. These contradictions entangled the gay ministers in a double-bind (Watzlawick, Bavelas \& Jackson 1967:211).

The celibacy requirement is seen as discriminatory, inhumane and reiterating the Shame of being gay (Downs 2006:39; Müller 2013:12). Jonker (2012:12, 13) considers the resolution as reducing gay ministers to their sexuality. According to him, the celibacy requirement is both impractical and an impossible position on human sexuality. Muller (1997:175) compares the celibacy requirement to the heavy loads which the Pharisees laid upon the shoulders of people (Mt 23:4, 13).

Point 8 in the resolution, which acknowledges the discretion of local church councils to handle the differences on homosexuality in their congregations, is considered by gay people like Cilliers (2011:413) as a cowardly decision. It still sustains the constant fear of rejection and humiliation of gay Christians due to the confusing element of conditional inclusion.

In the context of this research these principles of the resolution are perceived as discriminatory against gay ministers. This discrimination is perceived as based on prejudice and stigmatisation. Ackermann (2005:391) reminded us that theological statements like those made at Synod meetings have practical implications. Therefore, in dealing with the sinful nature of stigma, the church should confront it and should help (gay) people to find hope in Scripture and in our traditions by conveying God's grace, mercy and compassion to (gay) people. Unfortunately, the general knowledge of people in congregations is often very limited on this subject. This often creates polarisation between leadership and ordinary members, because members expect guidance from their leaders on moral issues. Already in 2001 Anthonissen and Oberholzer (2001:194) proposed a solution to this situation through dialogue between the congregations and gay members of the DRC.

According to Benton (2008:316) the reiteration of prejudice and stigmatisation create categories of 'us' and 'you' or of an 'othering'. Cromer (2001:191) views the existence of an 'other' as important in the development of a social and cultural identity. The idea of dividing society into insiders and outsiders also feature in the church (Allport 1954; Cromer 2001).
According to research done by Seligman (1998:29) and Watzlawick 1993:13), not everyone who is stigmatised react in the same way. Some have more resilience than others. Watzlawick (1993:13) suggests that we badly need the unhappiness brought to us when things in our lives are not perfect. Seligman examined the target group of prejudice and oppression through his model for learnt helplessness (Seligman 1998:29, 30). Seligman suggested that the attribute of resilience in the face of defeat was not always an inborn trait, but could be acquired. Some people did not prevail, whilst others managed to pick themselves up and rebuild their lives.

In terms of prejudice change, research suggests that intergroup contact reduced intergroup prejudice (Pettigrew \& Tropp 2006:751). According to Maturana and Varela (1998), the challenge for bringing about the necessary perceptual change on both sides would be an ethical one. An effort would be necessary in order to find a domain for co-existence, where both the DRC and its gay ministers would work together in creating a common world. This would require a serious reflection on the need to require a better knowledge of the other, but also of oneself.

In order to gain a better understanding of gay unions or marriages voices from 'pre-modern', 'modern' and 'postmodern' times revealed different societal discourses on sexuality, marriage and religion. Those discourses impacted differently on gay unions or marriages because of different interpretations and meanings attached to it. Authors like Gerstenberger (2002:17) and Dreyer (2008b:504) remind us to take the cultural-historical contexts into account when interpreting biblical texts, and for instance an institution like marriage.

Dreyer (2008b:501, 502) views not only sexuality but also marriage as being socially constructed. The concept of marriage has undergone many changes in terms of structure and definition (Anderson, Browning \& Boyer 2002; Coontz 2000:10-15; Coontz 2012:22). The motive to marry changed from an arrangement regarding money, property and procreation to one of mutual love and personal fulfilment.

With the rise of the Roman Catholic Church in the eighth century, religion became interwoven into marriage and marriage became a sacrament. A marriage became legally recognised through the blessing of the priest. The Reformers like Luther rejected the idea of marriage as a sacrament. According to Luther (Fudge 2003:323-325), 'Marriage is a civil affair ... it has nothing to do with the church ...' Luther also strongly opposed the imposition of clerical celibacy. From the short history of marriage it became clear that marriage was not biblically instituted, but rather an institution that was socially constructed over time. Changes in the thinking about marriage are also underscored by Anderson et al. (2002:3). According to these authors, it was especially the psychological revolution during the 1960s with its emphasis on individual self-fulfilment and happiness 
over family obligation and responsibility which contributed much to these changed discourses about marriage. Boswell (1995:9) underscores how difficult it is to know exactly what pre-modern heterosexual and homosexual relationships entailed.

Same-sex unions or marriages have been a valuable institution for most of human history and most cultures have known about it all along. Homosexual and homo-erotic acts were known and practiced in the Near-Eastern world of antiquity, without any moral or religious judgement (Human 2007:37). Both the Old and the New Testaments offer texts that seem to refer to the issue of homosexuality. Genesis 19:1-29; Judges 19; Leviticus 18:22 and Leviticus 20:13; Romans 1:26-7, 1 Corinthians 6:9 and 1 Timothy 1:10. Although theological scholars differ in their interpretations of those texts (Du Toit 2007:165; Botha 2005; Groenewald 2007:104, 105; Germond 1997:220-225; Luther 1961:255; Potgieter \& Van Huyssteen 2002:100), it seems that the Bible does not say anything about loving same-sex relationships. Martin, a gay New Testament scholar, expressed some of his ideas on the interpretation of the Bible as follows:

Any interpretation of the Bible that hurts people, oppresses people, or destroys people cannot be the right interpretation, no matter how traditional, historical, or exegetical respectable. There can be no debate about how the fact that the church's stand on homosexuality has caused oppression, loneliness, selfhatred, violence, sickness, and suicide for millions of people. (Martin 1996:130, 131)

Nowhere in the four Gospels do we find any reference by Jesus to homosexuality. Germond (1997:203) puts it clearly that the redemption (or condemnation) of gay people does not depend on how people interpret the Bible. Christian believers are saved by grace alone (see also Muller 1997:176). In terms of unconditional love and inclusion in his engagement with people from all walks of life, Jesus sets an example to his followers of all times by challenging categories of exclusion.

Same-sex unions in pre-modern Europe were seen as natural (Boswell 1995:54; Germond 1997:222; Veith 1994:30, 31). Greek culture not only tolerated homosexuality, but even encouraged it. Neither Greek nor Roman law or religion considered homosexual eroticism as of less value or different from heterosexual eroticism. Both Greek and Roman societies merely assumed that adult males would be interested in sexual relationships with both males and females. Sex was considered as a social and not a moral issue. Boswell (1995:80) reports relationships and formal unions, even marriages between same-sex couples. The status of these marriages was comparable to heterosexual marriages.

Boswell $(1980: 187,188)$ suggests that same-sex relationships in Medieval Europe were especially associated with the clergy. Boswell reminds us that the regular clergy were bound by vows of celibacy and that efforts to prevent sexual activities could be seen in the light of assisting them to keep their vows.
Originally, same-sex unions were commonplace and legal in medieval Byzantine society, but a new discourse in terms of intolerance towards homosexuality emerged from the fourteenth century (Boswell 1995:218, 262, 263; Sullivan 2004:30-45). Corbett (1997:165) views the social and political change in Europe as reason for the intolerance. Christianity came under pressure from both the Muslim and the 'heretic' and a need arose to find a scapegoat for the decline of the old order. Various groups became marginalised: Jews, Muslims, lepers, witches, heretics, usurers and homosexual people. Boswell (1980:270) ascribes the intolerance in part to the quest for intellectual and institutional uniformity. One such an example was the collections of canon law combining Roman civil law with Christian religious principles in order to standardise clerical supervision for moral, ethical and legal problems. Due to such measures, gay people increasingly lived their lives less openly. The Stonewall riots in 1969, where gay people stood up against suppression proved to introduce the end for this period in which gay people were forced to remain in 'closets', thereby either suppressing their identities or living it underground (Grey 1992:175).

The postmodern era introduced a new paradigm where context, language, social constructionism and deconstruction became important in the meaning-making process of people's lived experiences (Doherty 1991:40, 41). Hoffman (1990:7) believes that we look at reality through different lenses that influence our interpretation of reality. Hoffman considers the value of a gender lens as exposing established assumptions in psychological theory that have been taken for granted (i.e. being gay is a pathology, or homosexual behaviour is, per sé, perverse). Pronk (1993:232,) for example, states that since the 1990s a fundamental change has occurred in the Western concept of nature regarding the debate on Romans 1:26, 27. This explains why biological and other causal explanations for homosexuality, like epigenetics ${ }^{3}$, are increasingly playing a role in the moral debate on the acceptability of homosexuality. The question may be asked whether this reasoning may not also be applied to a phenomenon such as paedophilia, which also seems to have biological roots. Paedophilia is seen as a psychiatric disorder in which a person older than 16 years is sexually attracted to a prepubescent child younger than 11 years old (Wikipedia 2015). In trying to address this question, another question should be asked: what is sin? Heyns (1978:178, 179; Heyns 1982:132) describes sin as primarily a breakdown in relationships between man with God, his neighbour and himself. In a paedophilic relationship there is no talk of a loving, committed relationship which serves the interest of both parties - which could be the case in a mature gay relationship. A mature gay relationship could be

3.According to Prof Michael Pepper, a world renowned scientist, director of the Institute for Cellular and Molecular Medicine and professor in the Department of Immunology at the University of Pretoria (SA), epigenetics is the process in which chemical changes are made to genes, which leads to them being switched on or of (gene expression and gene repression). Sometimes epi-marks (the chemical changes (gene expression and gene repression). Sometimes epi-marks (the chemical change responsible for changes in gene expression) from the unborn child's parents are not properly erased - this can lead to 'variations' in the person's genetics. 'Variations' do not refer to mistakes, but rather to differences from what is perceived to be the norm by society. Such variations can lead to high cholesterol, cystic fibrosis, diabetes or homosexuality. The factors that caused variations in gene-expression were present before birth; therefore it is not a conscious decision and was out of the person's control (Van Zuydam 2014). 
a fulfilling relationship between two consenting adults which uplifts the two partners instead of harming and abusing each other and would then not qualify as a sinful relationship per sé.

During postmodern times on the international level, numerous changes took place effecting gay unions or marriages (Karimi \& Thompson 2014). Some of these changes were in support of gay marriages, while others were banning gay marriages, even introducing harsh punishments for being overtly in a gay relationship (Beeld 2014:2). In South Africa, gay marriages were legalised on 30 November 2006. This ruling and the implementation of same-sex marriages were greeted with mixed reactions. Many Christian communities, including the DRC, objected directly or indirectly to the legislation (Bellingan 2006; Jackson 2006a:5; Jackson 2006b:6; Malan 2006). As far as the DRC was concerned, their objections resulted in the 2007 Resolution on Homosexuality (Algemene Sinode [NGK] 2007:8).

\section{The impact on gay ministers and gay candidate ministers}

The resolution caused immense suffering to the coresearchers due to the complete rejection they experienced as human beings by the church. They perceived themselves as not good enough for the church. Those who decided to make their gay relationships known were either immediately dismissed as ministers, or they lost their candidature to be legitimated. The immediate consequences were: no place to stay, no money, the bursary awarded by the DRC had to be repaid with immediate effect and no immediate hope of an income. Apart from the material consequences their hopes and dreams to be obedient to God's calling by becoming a minister, were shattered. Emotionally strained they overnight became the (gossip) talk of the town: one day they were still the minister baptising the children in the congregation and burying their dead; the next day they were treated like criminals without having committed any crime. They had to leave the ministry without even a farewell. Those who decided to remain celibate had to continuously 'guard their step' in order to hide their homosexual identity and to prevent possible (inevitable?) prejudice and discrimination with dire consequences.

A common concern amongst the co-researchers was that the DRC invalidated and belittled their calling from God. They considered it as inconceivable how the Church could have so much power to determine whom God had called and who not. One of the gay candidate ministers, Mark, felt the resolution deprived him of his passion to make a difference as a minister on a person-to -person basis. Bertus described how the resolution with its celibacy requirement came as a 'train smash' and derailed his momentum to become a minister. He experienced the resolution as disempowering and contributing to his feelings of inferiority and worthlessness. It reiterated the shame of being gay. As he put it: 'The DRC made me feel like a less worthy member, a less worthy minister and a less worthy human being: a second-hand everything.'
The societal pressure forced Rev André Muller into a relationship with someone from the opposite sex. He hoped this would help him to appear 'normal' and to escape feelings of inferiority and worthlessness. He believed marriage with a heterosexual person would 'cure' him from his homosexuality. The marriage did not last long. This can be seen as a direct impact of the resolution of the DRC. Whether the resolution was formulated in 2013, or 2007 or 1986 , nothing has actually changed over the years in terms of same-sex relationships for gay ministers. The requirements of the resolution caused immense strain on the co-researchers in same-sex relationships, so much so that one even had to go through a break-up. The co-researchers, who chose to remain in the DRC, but celibate, chose a life of loneliness without anyone to love or to have as a companion. Their needs to attach and to belong would always just remain dreams. An insensitive colleague of one co-researcher invited him to 'celebrate his celibacy'. The impact of the celibacy requirement landed two of the co-researchers in Denmar, a psychiatric clinic in Pretoria, where they were treated for anxiety and depression. Years ago a co-reseacher, $\mathrm{S}$, received aversion therapy, while shock therapy was recently administered to Bertus to relieve his depression. These treatments left them with negative side-effects, like temporary memory loss and erectile dysfunction.

In terms of engaging with members of the Curatorium (although the latter were bound by the requirements of the resolution) a co-researcher reported 'inhumane, unChristlike, unethical, malicious, impatient, hard, merciless, unsympathetic, clinical (like in a court of law), intimidating and without any pastoral care' treatment. This led to disillusionment with the DRC, because it seemed as if the church leaders were not open to dialogue and wanted to maintain the status quo. One co-researcher expressed the notion that it seemed as if the church leaders were guarding their own legacies in the church, thereby not wanting to be the leader under whose leadership gay ministers were accepted unconditionally.

Two co-researchers, Lulani and Mark, who could not be legitimated, expressed their disappointment because they could not deliver their probation sermons in the DRC. Lulani had to deliver her first sermon in the Presbyterian Church, while Mark had to deliver his first sermon in the Reforming (gay) Church. As they told me: 'There is only one first time that you stand on the pulpit'. Although both reported positively about their experiences, they did not even invite their family and friends with.

The humiliation and rejection experienced by some of the coresearchers caused a period during which they perceived to be without God and the church, even of perceived atheism, as described by Rev André Muller. Lulani felt that she did not need the church to serve the Lord and to remain faithful to her calling, because she found a different non-denominational congregation who accepted her just as she is. The pain of rejection made her cautious and she expressed her wariness 
in the following words: 'When I am with people who say they are atheists, I relax, but when I am with "church" people, I become tense. I fear their judgement.' Fortunately one of the co-researchers had a more positive experience with the DRC. The ridicule and humiliation that Charl experienced from the Reformed Churches and fellow students at the NWU moved him to join the DRC at Vanderbijlpark. The congregation there set an example of love, inclusion and acceptance. According to him, they restored his dignity. A co-researcher, S, who chose to remain celibate throughout his career as a DRC minister, and who went on early retirement, referred to himself as a traveller searching for a different God from the God of the DRC. According to him, the God of the DRC murdered him emotionally, spiritually and financially. Another coresearcher, Mark, who was also denied to be legitimated, referred to himself as a post-institutionalised Christian, angry with the Church, but still contributing in different ways.

Regardless of the devastating impacts of the resolution on the lives of the co-researchers, I was inspired by their resilience and the alternative stories which developed from their misery. André Muller, who played a major role in the legalisation of gay marriages in South Africa on 30 November 2006, started a church for gay Christians twenty two years ago. Another co-researcher, Bertus, who chose to remain celibate, believes he can still be faithful to his calling by bringing unconditional love to other people, provided that nobody will 'discover' his homosexuality. Mark, still angry with the Church, managed to part with his dominant story of being the underdog. He realised he is on route to authenticity and can apply his many skills in the service of the Lord. Regrettably S, who lived a life of celibacy in the DRC and who went on early retirement has become lonely, angry and despondent. He considers his life as a minister in the church as a 'wasted life'. According to him, the full impact of the resolution after a lifelong struggle to deny his homosexuality is trying to get the better of him now. Negative thoughts are trying to convince him that ending his life journey would be the only way out of this misery.

In the telling, retelling and reliving the stories of the coresearchers and by interpreting their descriptions of their experiences, I kept in mind the tentative, preliminary and temporality of the meanings that were co-constructed.

\section{A post-foundational perspective}

Through the responses of the three interdisciplinary participants, their empathy towards the gay ministers was proof of a heightened sensitivity for the human condition. They were deeply aware of the sincerity of the gay ministers in terms of their calling to become ministers. The prejudice and discrimination, and the inconsistencies in the resolution were underscored. Both Botes (Social Work) and Jordaan (Psychology) expressed concerns about psychological scarring like anxiety, fear of exposure, self-reproach, sin delusion, isolation and withdrawal, loneliness, feelings of rejection and inhibited creativity. Jordaan was also concerned about the double-bind in the resolution (Algemene Sinode [NGK] 2007:8) and considered it as 'the worst kinds of life-defeating situations which leave no room for meaningful living and is totally disempowering'. According to him, people trapped in a double-bind may develop psycho-pathological symptoms like inducing schizophrenic behaviour.

Wiechers (Law) suggested a review of the fairness of the DRC's discrimination. According to Wiechers, the celibacy requirement from the resolution (Algemene Sinode [NGK] 2007:8) denies gay ministers the hope and possibility to live full lives, thereby encroaching on their inherent dignity and the right to have their dignity respected and protected'.

The accusation was also levelled against the DRC that they chose to be followers and not leaders that think ahead and who embrace God's diversity unconditionally.

\section{Possible contributions of the research}

The main contribution of this research is viewed to add to the existing body of knowledge. It informs any debate on the topic of gay Christians, in particular those debates on gay clergy, by documenting how the 2007 resolution impacts to this day on their lives. This research gives insight into how gay ministers experience decisions that are taken unilaterally - by non-gay people. In that sense it has the potential to sensitise communities of faith and beyond to the suffering of gay people, especially gay ministers. Before this research little or nothing was known about such impacts. After this research, no decisions like those entailed in the resolution of 2007 dare ignore the consequences.

\section{Impact of the research on the local community}

This research could have the following impacts on the local community:

\section{Revisiting the resolution}

The issue of the gay ministers' celibacy requirement is on the agenda for 2015 General Synod. The findings of this research should be disseminated to the new task team who has to serve the General Synod with a report on gay relationships and gay marriages (Algemene Sinode [NGK] 2013a). The new task team and the General Synod of 2015 should ethically respond to the new body of knowledge offered by this research.

\section{Admission of theology students}

This research suggests transparency to gay students during registration in terms of the implications according to the stipulations in the Resolution.

\section{Impact of the research beyond the local community}

For research to have an impact beyond the local community Müller $(2005: 85,86)$ suggests various ways of dissemination. He recommends group work, workshops and/or seminars 
held with stakeholders, like academic institutions and different congregations of the DRC. Another way of dissemination could also be through radio and television interviews and panel discussions. It can also be done through concentrically disseminating the research results to various communities of faith different form the DRC, including gay communities of faith. This could serve as a prophetic voice, sensitising the DRC and other communities of faith to the impact of the resolution on gay ministers, thereby inviting them to respond in an ethical way.

\section{Recommendations for further research}

Exploring the financial, emotional and spiritual impact the resolution had on many other people or groups of people, like parents, family and friends of gay ministers could be valuable. Similarly, the impact on those church members who reject homosexuality should also be explored. This will give them a voice in terms of how their church is changing due to the changes in resolutions with regard to gay people, especially gay ministers.

Another area for research could be how to change prejudice. Pettigrew and Tropp (2006:751) recommended intergroup contact. The ideas of Maturana and Varela (1998) on conflict resolution, namely to find a domain for co-existence, seemed valuable.

It should also be imperative to assess if the interpretation of the constitution in terms of the fairness of the discrimination levelled against gay ministers is just.

A last suggestion to consider for further research is the feasibility of starting a specialised ministry for gay people in the DRC, similar to the Andrew Murray congregations.

Since 1986 much progress in terms of accommodating gay people, including gay ministers, has been made by the resolutions taken by different Synod meetings of the DRC up till 2013. The 2007 General Synod Resolution of the Dutch Reformed Church on gay ministers with its celibacy requirement for gay ministers rules out intimate and sexual relationships, while marriage remains impossible. It unequivocally sentences a gay minister or gay candidate minister to remain single for life; unable to love and unable to be loved. This research studied the impact of the resolution on gay ministers in a qualitative way, thereby bringing authentic perspectives to the debate on gay relationships.

\section{Acknowledgements}

I confirm that I wrote the article based on my PhD thesis submitted in 2014. Professor Julian Müller was the supervisor.

\section{Competing interests}

The author declares that she has no financial or personal relationships which may have inappropriately influenced her in writing this article.

\section{References}

Ackermann, D.M., 2005, 'Engaging stigma: An embodied theological response to HIV and AIDS. The challenge of HIV/AIDS to Christian theology', Scriptura: International Journal of Bible, Religion and Theology in Southern Africa 89, 385-395.

Algemene Sinode [NGK], 1986, Besluiteregister, Kerkargief, Stellenbosch.

Algemene Sinode [NGK], 2002, Besluiteregister, Kerkargief, Stellenbosch.

Algemene Sinode [NGK], 2004, Besluiteregister, Kerkargief, Stellenbosch.

Algemene Sinode [NGK], 2007, Besluiteregister, Kerkargief, Stellenbosch.

Algemene Sinode [NGK], 2013a, Besluiteregister, besigtig 26 Julie 2014, by http:// www.ngk-tvl.org.za/Besluite $\% 20$ Alg\%20Sinode $\% 202013$.pdf

Algemene Sinode [NGK], 2013b, Die Kerkorde, NGK, Hatfield.

Allport, G.W., 1954, The nature of prejudice, Addison-Wesley, Cambridge.

Anderson, K., Browning, D. \& Boyer, B., 2002, Marriage just a piece of paper? Eerdmans Pub Co., Cambridge.

Anthonissen, C. \& Oberholzer, P., 2001, Gelowig en gay? Riglyne vir sinvolle dialoog met gay lidmate in die gemeente, Lux Verbi, Kaapstad.

Bellingan, M., 2006, 'Ek trou nie gays, sê Ray', Rapport, 22 Oktober.

Benton, K.W., 2008, 'Saints and sinners: training Papua New Guinean (PNG) Christian clergy to respond to HIV and AIDS using a model of care', Journal of Religion and Health 47, 314-325. http://dx.doi.org/10.1007/510943-007-9158-6

Bontempo, D.E. \& D’Augelli, A.R., 2002, 'Effects of at-school victimization and sexual orientation on lesbian, gay, bisexual youths' health risk behavior', Journal of Adolescent Health 30, 364-374.

Boswell, J., 1980, Christianity, social tolerance, and homosexuality, University of Chicago Press, Chicago, IL.

Boswell, J., 1995, Same-sex unions in premodern Europe, Random House, New York, NY. Botha, P., 2005, The Bible and homosex; sexual truths for a modern society, Khanya Press, Kranskop.

Cacioppo, J.T., Hawkley, L.C., Crawford, L.E., Ernst, J.M., Burleson, M.H., Ray, B., et al., 2002, 'Loneliness and health: potential mechanisms', Psychosomatic Medicine 64 407-417.

Cacioppo, J.T., Hughes, M.E., Waite, L.J., Hawkley, L.C. \& Thisted, R.A., 2006. 'Loneliness as a specific risk factor for depressive symptoms: Cross-sectional and longitudinal analyses', Psychology and Aging 21(1), 140-151.

Cilliers, P., 2011, Soeker, Protea Boekhuis, Pretoria.

Clandinin, D.J. \& Connely, F.M., 1994, 'Personal experience methods', in N.K. Denzin \& Y.S. Lincoln (eds.), The handbook of qualitative research, pp. 413-427, Sage, London.

Coontz, S., 2000, 'Marriage: Then and now', National Forum 80(3), 81-82.

Coontz, S., 2012, 'Mating games. Changing rules for sex and marriage', Christian Century, January 25, 22-24.

Corbett, I.D., 1997, 'Homosexuality in the traditions of the church', in P. Germond \& S. De Gruchy, (eds.), Aliens in the household of God. Homosexuality and Christian faith in South Africa, pp. 162-172, David Philip, Cape Town.

Cromer, G., 2001, 'Amalek as other, other as Amalek: Interpreting a violent biblical narrative', Qualitative Sociology 24(2), 191-202.

Denzin, N.K. \& Lincoln, Y.S. (eds.), 1994, The handbook of qualitative research, Sage, London.

Doherty, W.J., 1991, 'Family therapy goes postmodern', Networker, September/ October, 37-42.

Downs, A., 2006, The velvet rage: Overcoming the pain of growing up gay in a straight man's world, De Capo Press, Cambridge.

Dreyer, Y., 2008a, 'Pastoral care and gays against the background of same-sex relationships in the Umwelt of the New Testament', HTS Teologiese Studies/ Theological Studies 64(2), 739-765. http://dx.doi.org/10.4102/hts.v64i2.42

Dreyer, Y., 2008b, 'The "sanctity" of marriage - an archaeology of a socio-religious construct: Mythological origins, forms and models', HTS Teologiese Studies/ Theological Studies 64(1), 499-527. http://dx.doi.org/10.4102/hts.v64i1.10

Du Toit, A., 2007, 'Maar die grootste hiervan is die liefde - oor homoseksualiteit in Romeine 1', in C. Vos \& D. Human (reds.), Liefde is die grootste. Oor erotiek en seksualiteit, bl. 161-171, Protea Boekhuis, Pretoria.

Freedman, J. \& Combs, G., 1996, Narrative therapy. The social construction of preferred realities, Norton, New York, NY.

Fudge, T.A., 2003, 'Incest and lust in Luther's marriage: Theology and morality in Reformation polemics', Sixteenth Century Journal XXXIV(2), 319-345.

Germond, P., 1997, 'Heterosexism, homosexuality and the Bible', in P. Germond \& S. De Gruchy (eds.), Aliens in the household of God. Homosexuality and Christian faith in South Africa, pp. 188-232, David Philip, Cape Town.

Gerstenberger, E., 2002, Theologies in the Old Testament, Transl. J. Bowden, T \& T Clark, London.

Grey, A., 1992, Quest for justice towards homosexual emancipation, SinclairStevenson, London.

Groenewald, A., 2007, 'Drink met vreugde uit die liefdesfontein!'n Ou-Testamentiese perspektief op menslike seksualiteit', in C. Vos \& D. Human (reds.), Liefde is die grootste. Oor erotiek en seksualiteit, bl. 90-108, Protea Boekhuis, Pretoria. 
Heshusius, L., 1994, 'Freeing ourselves from objectivity: Managing subjectivity or turning toward a participatory mode of consciousness?' Educational researcher 23(3), 15-22.

Heyns, J.A., 1978, Dogmatiek, N.G. Kerkboekhandel, Pretoria.

Heyns, J.A., 1882, Teologiese etiek. Deel 1, N.G. Kerkboekhandel, Pretoria.

Hilkert, M.C., 2005, 'Edward Schillebeeckx, OP (1914-): Encountering God in a secular and suffering world', Theology Today 62, 376-87.

Hoffman, L., 1990, 'Constructing realities: An art of lenses', Family Process, 29 March, 1-12.

Human, D.J., 2007, 'Om by die grense van die "ek" verby te steek ... Erotiek en seksualiteit in die Ou Nabye Ooste', in C. Vos \& D. Human (reds.), Liefde is die grootste. Oor erotiek en seksualiteit, bl. 16-45, Protea Boekhuis, Pretoria.

Jackson, N., 2006a, 'Christene beoog optog teen gay-troues', Beeld, 11 Augustus, bl. 5 .

Jackson, N., 2006b, 'NG Kerk staan by definisie van huwelik van 1 man, 1 vrou', Beeld, 19 Oktober, bl. 6 .

Jackson, N., 2013, 'Sinode hoor: "Wens ek's gay"', Beeld, 11 Oktober, bl. 3.

Jonker, L., 2012, 'Driegesprek. Gaydominees: 3 stemme', in Kerkbode, 20 Januarie, bl. 12, 13.

Karimi, F. \& Thompson, N., 2014, 'Uganda's president Museveni signs controversial antigay law into law', in CNN, viewed 25 February 2014, from http://www.cnn. com/2014/02/24/world/africa/uganda-anti-gay-bill/

Kotzé, D., 2002, 'Doing participatory ethics', in D. Kotzé, J. Myburg, J. Roux \& Associates (eds.), Ethical ways of being, pp. 1-34, Ethics Alive, Pretoria.

Luther, M., 1961, Luther's Works. Lectures on Genesis, ch 15-20, ed. Jaroslav Pelikan, vol. 3, p. 255, Concordia Publishing House, Saint Louis, MO.

Malan, M., 2006, 'NG Kerk-sinode besluit eers in 2007 oor gay-huwelike', Rapport, 22 Oktober.

Martin, D.B., 1996, Arsenokoitês and malakos: Meanings and consequences', in R.L. Brawley (ed.), Biblical ethics \& homosexuality: Listening to Scripture, pp. 117-136, Westminster, Louisville, K.Y.

Maturana, H.R. \& Varela, F.J., 1998, The tree of knowledge: The biological roots of human understanding, Shambhala, Boston, MA.

McLean, C., Carey, M. \& White, C. (eds.), 1996, Men's ways of being, Westview Press, CO.

McTaggert, R., 1997, Participatory action research. International contexts and consequences, State University of New York Press, Albany, NY.

Morgan, A., 2000, What is narrative therapy? An easy-to-read introduction, Dulwich Centre Publications, Adelaide.

Muller, A., 1997, 'My ministry in the gay community' in P. Germond \& S. De Gruchy, (eds.), Aliens in the household of God. Homosexuality and Christian faith in South Africa, pp. 173-177, David Philip, Cape Town.

Müller, J.C., 2005, 'A postfoundationalist, HIV-positive practical theology', Practical Theology in South Africa 20(2), 72-88.

Müller, J.C., 2009, 'Postfoundationalism as a practical way of interdisciplinary work: Narrative research on HIV and Aids', Practical Theology in South Africa 24(2), 199-228
Müller, J.C., 2011, 'Postfoundational practical theology for a time of transition', HTS Teologiese studies/Theological Studies 67(1), Art.\#837, 5 pages, http://dx.doi. org/10.4102/hts.v 67i1.837

Müller, J.C., 2013, 'Hopelik kan NG Kerk uitdaag oor gays', Beeld, 09 Oktober, bl. 12.

Müller, J.C. \& Schoeman, K., 2004, 'Narrative research: A respectful and fragile intervention', Sociale Interventie 13(3), 7-13.

Nederduitse Gereformeerde Kerk Suid-Transvaal, 2001, Verslag aan die moderamen.

Oosthuizen, J., 2007, 'Absolute vreugde na uitspraak' Sinodebode, 08 Junie, (5), bl. 3.

Pettigrew, T.F. \& Tropp, L.R., 2006, 'A meta-analytic test of intergroup contact theory', Journal of personality and social psychology 90(5), 751-783.

Pienaar, A., 2007, 'Sinodegangers verlig oor gay besluit', Sinodebode, 08 Junie, (5), bl. 3. Potgieter, J. \& Van Huyssteen, F., 2002, Homoseksualiteit in perspektief. Hoop en heling uit die Bybel, Lux Verbi, Wellington.

Pronk, P., 1993, Against nature? Types of moral argumentation regarding homosexuality, Eerdmans Pub. Co., Grand Rapids, MI.

Schwandt, T. A., 1994, 'Constructivist, interpretivist approaches to human inquiry', in N.K. Denzin \& Y.S. Lincoln (eds.), The handbook of qualitative research, pp.118-137, Sage, London.

Seligman, M.E.P., 1998, Learned optimism. How to change your mind and your life, Free Press, New York, NY.

Sullivan, A. (ed.), 2004, Same-sex marriage: pro and con. A reader, Vintage Books, New York, NY.

'Talle gays in Nigerië gearresteer. Leier bekragtig wet stil', Die Beeld, 14 Januarie 2014 besigtig 15 Januarie 2014, by http://www.beeld.com/nuus/2014-01-14-tallegays-in-nigerie-gearresteer.

Van Huyssteen, J.W., 2000, 'Faith and knowledge: Our common evolutionary heritage', in C.W. du Toit (ed.), Evolution and creativity, pp. 181-216, Research Institute for in C.W. du Toit (ed.), Evolution and creativity, pp. 181-216,
Theology and Religion, University of South Africa, Pretoria.

Van Huyssteen, J.W., 1993, 'Is the Postmodernist always a postfoundationalist?', Theology Today 50, 377.

Van Huyssteen, J.W., 2007, A brief overview of a theologian's journey to interdisciplinarity, Theological Seminary, Princeton, NJ.

Van Loggerenberg, M.P., 2008, 'Deconstructing gay discourse in the Dutch Reformed Church', dissertation for M.Th degree, UNISA, Pretoria.

Van Zuydam, 2014, 'Being gay is no conscious decision - expert,' in IOL, viewed 28 May 2014, from http://www.iol.co.za/lifestyle/people/being-gay-is-no-consciousdecision-expert-1.164

Veith, G.E., 1994, Postmodern times; a Christian quide to contemporary thought and culture, Crossway Books, Wheaton, IL.

Watzlawick, P., 1993, The situation is hopeless, but not serious. The pursuit of unhappiness, Norton \& Co., New York, NY.

Watzlawick, P., Bavelas, J.B. \& Jackson, D.D., 1967, Pragmatics of human communication: A study of interactional patterns, pathologies, and paradoxes, Norton \& Co., New York, NY.

Wikipedia, 2015, s.v. 'Pedophilia', viewed 17 March 2015, from http://en.wikipedia. org/wiki/Pedophilia 